Pediatr. Res. 17: 195-199 (1983)

\title{
Organ Tissue Blood Flow Responses to Hypoxemia in Lambs: Effect of Angiotensin Converting Enzyme Inhibitor
}

\author{
DOUGLAS N. WEISMANN, ${ }^{(35)}$ JAMES E. HERRIG, OLIVA J. MCWEENY, AND \\ JEAN E. ROBILLARD \\ Department of Pediatrics and the Cardiovascular Center, University of Iowa, Iowa City, Iowa, USA
}

\section{Summary}

Chronically-catheterized lambs $(n=21), 2-38$ days of age, were studied to test the hypothesis that the products of angiotensin converting enzyme (ACE) activity are involved in control of baseline arterial pressure and organ tissue blood flow and the redistribution of organ tissue blood flow in response to normocapnic hypoxemia in the maturing lamb. ACE activity was inhibited by administration of captopril $[2.5 \mu \mathrm{g} /(\mathrm{kg} \bullet \mathrm{min})]$, which significantly $(P<0.01)$ decreased arterial concentrations (mean \pm S.D.) of angiotensin-II (from $105.0 \pm 33.9$ to $67.0 \pm 25.9 \mathrm{pg} / \mathrm{ml}$ ) and aldosterone (from $115.0 \pm 105.0$ to $53.8 \pm 28.6 \mathrm{pg} / \mathrm{ml}$ ) and inhibited by greater than $90 \%$ the vasopressor response to an intravenous bolus of angiotensin-I $(1 \mu \mathrm{g} / \mathrm{kg})$. Baseline mean arterial pressure was significantly $(P<0.01)$ decreased from $78 \pm 8$ to $66 \pm 10$ $\mathrm{mmHg})$ and remained depressed during hypoxemia $(67 \pm 12$ $\mathrm{mmHg})$ and recovery $(62 \pm 9 \mathrm{mmHg})$ periods. Baseline heart rate was unchanged by ACE inhibition (from $181 \pm 33$ to $188 \pm 35$ beats $/ \mathrm{min})$ but increased $(P<0.01)$ significantly in response to hypoxemia (to $233 \pm 52$ beats/min). Baseline heart, adrenal, jejunum, ileum, and skeletal muscle tissue blood flow, measured by radiolabeled microspheres, were not significantly $(P>0.05)$ changed by ACE inhibitor. Baseline liver tissue blood flow increased slightly [from $0.10 \pm 0.10$ to $0.16 \pm 0.12 \mathrm{ml} /(\mathrm{min} \cdot \mathrm{g})$ ] but significantly $(P<0.05)$ during $\mathrm{ACE}$ inhibitor treatment, and spleen tissue blood flow decreased significantly [from $2.54 \pm 1.03$ to 1.31 $\pm 0.61 \mathrm{ml} /(\mathrm{min} \cdot \mathrm{g})]$. Normocapnic hypoxemia $\left(\mathrm{Po}_{2} 42 \pm 6\right.$ torr; oxyhemoglobin saturation $50.7 \pm 18.0 \%$ ) for 30 min during $\mathrm{ACE}$ inhibition was associated with increased $(P<0.01)$ heart [from $2.72 \pm 1.52$ to $8.87 \pm 5.78 \mathrm{ml} /(\mathrm{min} \cdot \mathrm{g})$ ] and adrenal [from $2.75 \pm$ 1.88 to $6.43 \pm 2.82 \mathrm{ml} /(\min \cdot \mathrm{g})]$ tissue blood flow, decreased $(P$ $<0.01)$ spleen [from $1.31 \pm 0.60$ to $0.48 \pm 0.57 \mathrm{ml} /(\mathrm{min} \cdot \mathrm{g})$ ] tissue blood flow, and unchanged $(P>0.05)$ blood flow to jejunum Ifrom $2.51 \pm 0.67$ to $2.63 \pm 2.00 \mathrm{ml} /(\mathrm{min} \cdot \mathrm{g})$ ], ileum [from $0.82 \pm 0.28$ to $0.84 \pm 0.42 \mathrm{ml} /(\mathrm{min} \cdot \mathrm{g})$ ], liver [from $0.19 \pm 0.13$ to $0.43 \pm 0.41$ $\mathrm{ml} /(\mathrm{min} \cdot \mathrm{g})]$ and skeletal muscle [from $0.11 \pm 0.09$ to $0.48 \pm 0.57$ $\mathrm{ml} /(\min \cdot \mathrm{g})]$ tissues. Responses to hypoxemia were similar in control lambs, except that comparisons of the change $(\Delta)$ in tissue blood flow in response to hypoxemia in control versus captopriltreated lambs for ileum $[\Delta$ ileum $-0.32 \pm 0.29$ versus $0.03 \pm 0.40$ $\mathrm{ml} /(\mathrm{min} \cdot \mathrm{g})]$ and jejunum $[\Delta \mathrm{jejunum}-1.60 \pm 2.20$ versus $0.60 \pm$ $2.00 \mathrm{ml} /(\mathrm{min} \cdot \mathrm{g})]$ demonstrated a greater fall in blood flow to these tissues in response to hypoxemia in control lambs. Thus, the products of ACE may be important in maintenance of baseline arterial pressure in the maturing animal. Furthermore, these products may be important in splanchnic vasoconstrictive responses to stress such as hypoxemia in the maturing animal.

Abbreviations

AI, angiotensin I

AII, angiotensin II

$A C E$, angiotensin converting enzyme
Aldo, aldosterone

$\mathrm{HR}$, heart rate

MAP, mean arterial pressure

RAA, renin-angiotensin-aldosterone

Activity of the renin-angiotensin-aldosterone (RAA) system is increased in newborns in comparison to adults $(12,15,18-20,24$, $25)$, and decreases rapidly with increasing postnatal age $(6,10,23$, $25,27,29)$. Responsiveness of this system may also vary with postnatal age (29). The contribution of this system to the control of organ tissue blood flow in newborn animals is unknown. Furthermore, its importance in pathophysiologic conditions, such as hypoxemia, during maturation is not clear. Activity of RAA system is increased in response to hypoxemia $(1,14,22,30,32)$ and is accompanied by a redistribution of organ tissue arterial blood flow $(2,3,31)$. The present study was undertaken to examine the contribution of the RAA system to control of baseline arterial pressure and organ tissue blood flow and the redistribution of organ tissue blood flow in response to normocapnic hypoxemia in the maturing animal. The role of the RAA system in organ tissue blood flow under these conditions was examined by interruption of the RAA system with the angiotensin converting enzyme inhibitor, captopril, in chronically-catheterized lambs. Organ tissue arterial blood flow responses to hypoxemia during angiotensin-converting enzyme inhibition were compared to uninhibited responses to normocapnic hypoxemia in control lambs.

\section{MATERIALS AND METHODS}

Mixed breed Dorset-Suffolk lambs were housed with the maternal ewe in the University Animal Care Unit. Lambs were selected for experimental procedures according to their postnatal age.

Surgical procedures. Surgical procedures in these lambs have been previously described (31). Briefly, chronic catheters were placed in each femoral vessel so that their tips were located in the distal aorta, left ventricular chamber, and distal vena cava, respectively. The lambs were administered glucose-saline solution intravenously during the postoperative period until they were able to stand and feed by mouth, which was usually within $4 \mathrm{~h}$ of the operative procedures. Thereafter, the lamb nursed from the ewe ad libitum. The lambs were allowed $72 \mathrm{~h}$ for recovery from: the operative procedures before participation in the experimental protocol.

Experimental protocol. Lambs were studied over a range of postnatal age (Captopril-treated group: 4-38 days, mean age 15 \pm 10 days, $n=13$; Control group: $2-22$ days, mean age $10 \pm 9$ days, $n=8$ ). Studies of these lambs were performed while the lambs were supported in a standing posture by a specially designed canvas harness. Arterial blood pressure (MAP) was recorded continuously on a Beckman R611 Dynograph using a pressure transducer (Statham) connected to the femoral artery catheter. 
Heart rate (HR) was also continuously recorded with a cardiotachometer triggered from the arterial pressure pulse wave. In each lamb a $5 \%$ dextrose $0.2 \mathrm{~N}$ saline solution was administered as a constant intravenous infusion at a rate of $0.4 \mathrm{ml} / \mathrm{min}$ by a Harvard infusion/withdrawal pump. After a $1 \mathrm{~h}$ equilibration, baseline arterial pressure response to an intravenous bolus of saline, angiotensin-I (AI, $1 \mu \mathrm{g} / \mathrm{kg}$ ) and angiotensin-II (AII, $0.5 \mu \mathrm{g} / \mathrm{kg}$ ) was determined. Arterial blood was also sampled for pre-inhibitor hematocrit, hemoglobin concentration, oxyhemoglobin saturation, $\mathrm{pH}, \mathrm{PCO}_{2}, \mathrm{AII}$ and aldosterone (Aldo) determinations. Withdrawn blood was volumetrically replaced with plasma protein fraction (Plasmanate, Cutter Laboratories). Subsequently, approximately $1.5 \times 10^{6}$ microspheres (3M Company), $15 \pm 3 \mu \mathrm{m}$ in diameter and labeled with a single radioactive isotope $\left({ }^{141} \mathrm{Ce},{ }^{85} \mathrm{Sr},{ }^{46} \mathrm{Sc}\right.$, or ${ }^{95} \mathrm{Nb}$ ), were suspended in $3 \mathrm{ml}$ of $0.9 \%$ saline. The microspheres were then agitated thoroughly and injected into the left ventricular catheter over 20-30 sec, then flushed immediately with $5 \mathrm{ml}$ of $0.9 \%$ saline solution. An independent lower body reference sample was obtained by withdrawal of blood (Harvard infusion/withdrawal pump) through the left femoral arterial catheter at a rate of $1.94 \mathrm{ml} / \mathrm{min}$ for a period of $3 \mathrm{~min}$ starting approximately 20 $\mathrm{sec}$ before the microspheres injection (13).

After these baseline determinations captopril (Squibb), which was generously supplied by Dr. Z. P. Horovitz, was solubilized in $0.9 \%$ saline solution and immediately given as a constant intravenous infusion at a rate of $2.5 \mu \mathrm{g} /(\mathrm{kg} \cdot \min )(40 \mu \mathrm{l} / \mathrm{min})$. Control lambs received vehicle (saline) only. After a 60-min equilibration period, adequacy of converting enzyme inhibition was documented in captopril-treated lambs as greater than $90 \%$ suppression of the arterial pressure response to an IV bolus of AI $(1 \mu \mathrm{g} / \mathrm{kg})$. Intact arterial pressure response to an IV bolus of AII $(0.5 \mu \mathrm{g} / \mathrm{kg})$ was also confirmed in each of these lambs. Thereafter, arterial blood was sampled for determinations of hematocrit, hemoglobin concentration, oxyhemoglobin saturation, $\mathrm{pH}, \mathrm{PCO}_{2}$, AII, and Aldo. Withdrawn blood was volumetrically replaced with plasmanate. A second injection of microspheres, labeled with a different radioactive isotope, was then performed and a reference flow determined as described previously.

Systemic hypoxemia was then produced during continuous captopril or vehicle infusion by directing a $12 \%$ oxygen in nitrogen gas mixture into a clear plastic bag, which was placed over the lamb's head and secured with a drawstring at the neck. Partial rebreathing of expired gases containing $\mathrm{CO}_{2}$ within the bag encircling the head occurred under these circumstances, so that hyperpnea produced by the hypoxemia would not induce hypocarbia. During this initial equilibration to the oxygen-deficient inhaled gas mixture, arterial blood $\mathrm{pH}$ and gases were monitored frequently for regulation of gas flow into the bag encircling the lamb's head. From these measurements and adjustments the desired degree of hypoxemia could be induced while maintaining $\mathrm{pH}$ and $\mathrm{PCO}_{2}$ in the normal range. Approximately $30 \mathrm{~min}$ after initiation of the oxygen-deficient inhaled gas mixture, appropriate $\mathrm{pH}, \mathrm{PCO}_{2}$ and $\mathrm{PO}_{2}$ values were confirmed by arterial blood gas analysis, along with determinations as in the previous periods. Sampled blood was again replaced volumetrically with plasmanate. An injection of radioactive microspheres, labeled with a different isotope, was then performed as described previously.

After the injection of microspheres during hypoxemia, normoxemia was restored by allowing the lamb to breathe room air with continued captopril or vehicle infusion. After $60 \mathrm{~min}$ of equilibration to normoxemia during continued captopril infusion, arterial blood was sampled for determinations, as in the previous periods, and was replaced volumetrically with plasmanate. A fourth injection of microspheres was performed, as described previously, followed by documentation of persistent inhibition of vasopressor response to AI and continued reactivity to IV bolus of AII. The lamb was then sacrificed by intravenous bolus administration of pentobarbital sodium (Somlethal, Med-Tech, Inc.). Selected abdominothoracic organs were immediately harvested, and tissue samples of approximately $1 \mathrm{~g}$ were placed in counting vials.
Control lambs were studied in an identical fashion except for lack of determinations of AII and Aldo.

Analytical procedures. Arterial blood $\mathrm{pH}, \mathrm{PO}_{2}$ and $\mathrm{PCO}_{2}$ were determined by a Radiometer $\mathrm{pH} /$ blood gas analyzer. Hemoglobin concentration and oxyhemoglobin saturation were determined by an IL Cooximeter, which had been calibrated previously for lamb's blood. Radiolabeled microsphere $\left({ }^{85} \mathrm{Sr},{ }^{141} \mathrm{Ce},{ }^{46} \mathrm{Sc},{ }^{95} \mathrm{Nb}\right)$ content in blood and tissue was determined by counting in a gamma spectrometer (Beckman 300) with isotope separation by standard methods (9). Hematocrit was determined by standard micro-methodology. Arterial Aldo (21) and AII (4) measurements were performed by radioimmunoassay in the Cardiovascular Center Core Laboratory at the University of Iowa.

Calculations. Organ tissue blood flow was calculated as follows: organ tissue counts $\times$ femoral artery reference flow rate/total femoral blood counts.

Data analysis. Comparisons were performed by student's paired or unpaired $t$ test with appropriate adjustment of the critical $t$ value according to the number of sequential comparisons performed (28). A two-sided significant limit $P$ value of 0.05 or less was required for a difference to be declared significant. Experimental data are expressed as mean \pm S.D.

\section{RESULTS}

Administration of the angiotensin converting enzyme (ACE) inhibitor, captopril, to chronically-catheterized lambs was associated with significantly decreased arterial AII (from $105.0 \pm 33.9$ to $67.0 \pm 25.9 \mathrm{pg} / \mathrm{ml}, P<0.01$ ) concentrations. The arterial Aldo concentrations were quite variable and the fall in Aldo with captopril infusion failed to reach statistical significance by Student's paired $t$ test; however, 11 of 13 lambs responded to captopril with decreased arterial Aldo concentration. This change (from $11.5 \pm 105.0$ to $53.8 \pm 28.6 \mathrm{pg} / \mathrm{ml})$ was statistically significant $(P$ $<0.01$ ) by Wilcoxon's signed rank test. The vasopressor effect (the change in mean arterial pressure, $\triangle \mathrm{MAP})$ of AI $(1 \mu \mathrm{g} / \mathrm{kg})$ was greater than $90 \%$ inhibited by captopril infusion ( $\triangle$ MAP $28 \pm 10$ $\mathrm{mmHg}$ pre-captopril versus $2 \pm 3 \mathrm{mmHg}$ post-captopril) without affecting vasopressor response ( $\triangle \mathrm{MAP} 29 \pm 9 \mathrm{mmHg})$ to AII $(0.5$ $\mu \mathrm{g} / \mathrm{kg}$ ). Continued suppression of AI vasopressor response ( $\triangle \mathrm{MAP}$ $2 \pm 2 \mathrm{mmHg}$ after recovery period) as well as suppression of arterial concentrations of AII $(75.6 \pm 19.5$ and $74.1 \pm 32.1 \mathrm{pg} / \mathrm{ml})$ and Aldo $(47.0 \pm 25.7$ and $41.0 \pm 21.5 \mathrm{pg} / \mathrm{ml})$ in hypoxemia and recovery periods, respectively, also were verified.

Arterial blood values of captopril-treated lambs are presented in Table 1. Inhibition of ACE activity with captopril was not associated with significant changes in arterial $\mathrm{Po}_{2}$, oxyhemoglobin, $\mathrm{PCO}_{2}, \mathrm{pH}$, hematocrit or hemoglobin. Administration of oxygendeficient inhaled gas mixture to these lambs during continuous infusion of captopril was associated with significant declines in arterial $\mathrm{PO}_{2}$ and oxyhemoglobin saturation without significant changes in arterial $\mathrm{PCO}_{2}, \mathrm{pH}$, hematocrit, and hemoglobin. Recov-

Table 1. Arterial blood values in lambs treated with angiotensin converting enzyme inhibitor ${ }^{1}$

\begin{tabular}{lcccc}
\hline & Baseline & Inhibitor $^{2}$ & $\begin{array}{c}\text { Inhibitor \& } \\
\text { hypoxemia }\end{array}$ & $\begin{array}{c}\text { Inhibitor \& } \\
\text { recovery }\end{array}$ \\
\hline $\mathrm{PO}_{2}$ (torr) & $96 \pm 7$ & $94 \pm 7$ & $42 \pm 6^{3}$ & $97 \pm 9$ \\
$\begin{array}{l}\text { Oxyhemoglobin } \\
\text { (\% saturation) }\end{array}$ & $91.3 \pm 4.1$ & $91.7 \pm 2.5$ & $50.7 \pm 18.0^{3}$ & $91.5 \pm 2.5$ \\
$\mathrm{PCO}_{2}$ (torr) & $31 \pm 3$ & $33 \pm 4$ & $35 \pm 9$ & $32 \pm 4$ \\
$\mathrm{pH}$ & $7.47 \pm 0.03$ & $7.47 \pm 0.04$ & $7.42 \pm 0.09$ & $7.44 \pm 0.05$ \\
Hematocrit (\%) & $28 \pm 6$ & $28 \pm 6$ & $29 \pm 6$ & $27 \pm 6^{3}$ \\
Hemoblogin & $9.7 \pm 2.0$ & $9.6 \pm 2.1$ & $10.2 \pm 2.1$ & $9.2 \pm 1.9^{3}$ \\
$\quad(\mathrm{~g} / \mathrm{dl})$ & & & &
\end{tabular}

\footnotetext{
${ }^{1}$ Values are mean \pm S.D., $n=13$

${ }^{2}$ Inhibitor, angiotensin converting enzyme inhibitor (captopril).

${ }^{3}$ Value is significantly different from inhibitor period, $P<0.05$.
} 
ery values during ACE inhibition were not significantly different from baseline except for hematocrit and hemoglobin. Lambs, which did not receive captopril (controls), had similar responses to administration of vehicle and the oxygen-deficient gas mixture (Table 2). Comparisons of the baseline values during infusion of the angiotensin converting enzyme inhibitor in captopril-treated lambs to baseline values during vehicle infusion in control lambs revealed small but significant differences $(P<0.05)$ for arterial $\mathrm{pH}$ and oxyhemoglobin saturation $\left(\mathrm{HbO}_{2}\right)$. The change $(\Delta)$ in values in response to hyporemia in captopril-treated lambs versus control lambs were not significantly different, except for $\mathrm{PCO}_{2}$ $\left(\Delta \mathrm{PCO}_{2}-5 \pm 5\right.$ versus $2 \pm 8$ torr in captopril-treated versus controls, respectively, $P<0.05$ ).

MAP was significantly decreased by ACE inhibitor infusion (Fig. 1). MAP remained depressed throughout hypoxemia and recovery periods. HR, on the other hand, did not change significantly in response to ACE inhibition (Fig. 1) despite the decrease in MAP. HR increased significantly in response to hypoxemia during ACE inhibition and returned to baseline during recovery periods. In control lambs (Fig. 2) MAP and HR were unchanged by infusion of vehicle. Hypoxemia in these lambs was associated with a significant increase in HR but no change in MAP. Recovery values were not significantly different from baseline values in these lambs. Baseline mean arterial pressure was significantly lower during inhibitor infusion in relation to baseline MAP during vehicle infusion in control lambs. On the other hand, the change in MAP and HR in response to hypoxemia were not significantly different in captopril-treated versus control lambs.

Table 2. Arterial blood values in control lambs ${ }^{1}$

\begin{tabular}{lcccc}
\hline & Baseline & Vehicle $^{2}$ & $\begin{array}{c}\text { Vehicle \& } \\
\text { hypoxemia }\end{array}$ & $\begin{array}{c}\text { Vehicle \& } \\
\text { recovery }\end{array}$ \\
\hline Po $_{2}$ (torr) & $87 \pm 13$ & $90 \pm 13$ & $37 \pm 6^{3}$ & $82 \pm 6$ \\
$\begin{array}{l}\text { Oxyhemoglobin } \\
\text { (\% saturation) }\end{array}$ & $94.0 \pm 2.7$ & $94.6 \pm 2.8$ & $63.0 \pm 8.3^{33}$ & $95.6 \pm 1.4$ \\
$\mathrm{PCO}_{2}$ (torr) & $35 \pm 5$ & $36 \pm 5$ & $31 \pm 3$ & $35 \pm 2$ \\
pH & $7.36 \pm 0.07$ & $7.37 \pm 0.07$ & $7.36 \pm 0.09$ & $7.33 \pm 0.09$ \\
Hematocrit $(\%)$ & $25 \pm 7$ & $24 \pm 8$ & $26 \pm 6$ & $24 \pm 8$ \\
Hemoglobin & $8.8 \pm 2.9$ & $8.6 \pm 2.9$ & $9.0 \pm 2.7$ & $8.3 \pm 3.0$ \\
$\quad(\mathrm{~g} / \mathrm{dl})$ & & & & \\
\hline
\end{tabular}

${ }^{1}$ Values are mean \pm S.D., $n=8$.

${ }^{2}$ Vehicle, solvent used in captopril solution ( $0.9 \%$ saline solution).

${ }^{3}$ Value is significantly different from vehicle period, $P<0.01$.

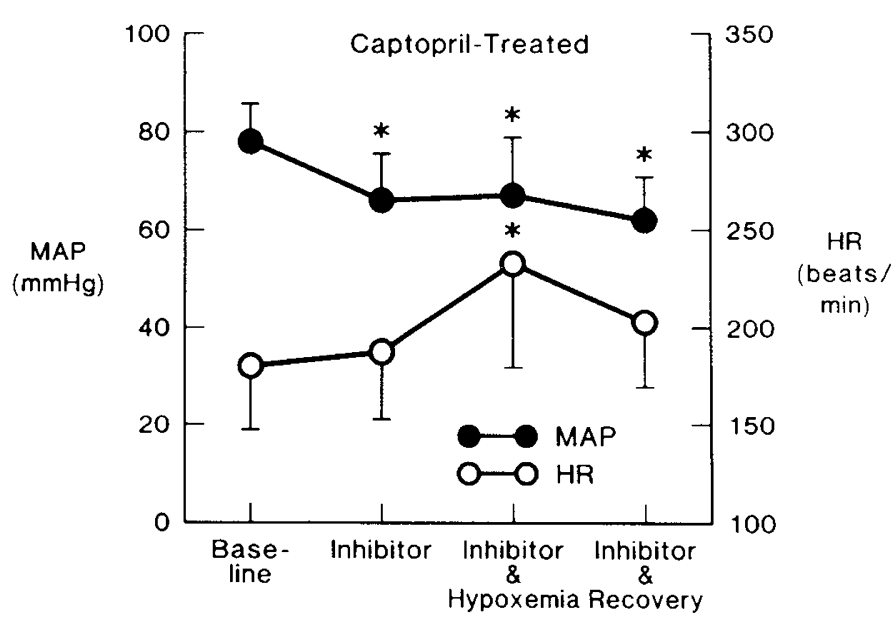

Fig. 1. Mean arterial pressure (MAP) and heart rate (HR) values under conditions of baseline, inhibition of converting enzyme (Inhibitor), inhibition of converting enzyme plus hypoxemia (Inhibitor \& Hypoxemia), and inhibition of converting enzyme plus recovery (Inhibitor \& Recovery) in captopril-treated lambs. Values are mean \pm S.D. $n=13$. Asterisk indicates that value is significantly different from baseline, $P<0.0$ l.

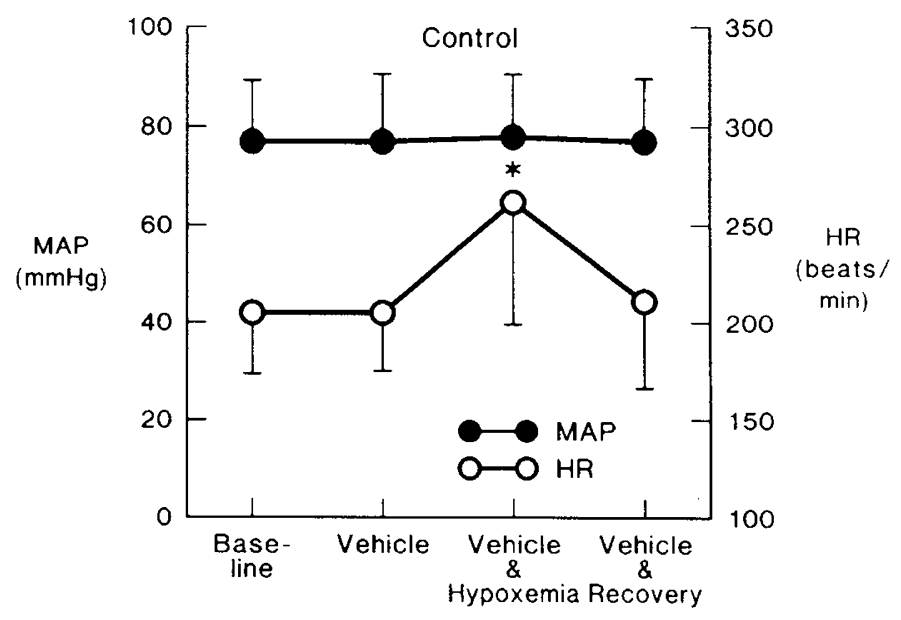

Fig. 2. Mean arterial pressure (MAP) and heart rate (HR) values under conditions of baseline, vehicle infusion (Vehicle), vehicle infusion plus hypoxemia (Vehicle \& Hypoxemia), and vehicle infusion plus recovery (Vehicle \& Recovery) in control lambs. Values are mean \pm S.D. $n=8$. The Vehicle \& Hypoxemia value for heart rate is significantly different from baseline, $P<0.05$.

Inhibition of ACE activity with captopril did not significantly change baseline organ tissue arterial blood flow to heart, adrenal, skeletal muscle (Fig. 3A), jejunum, or ileum (Fig. 3B). Baseline arterial blood flow to liver tissue increased significantly during captopril infusion, but the increase was very small (Fig. 3B). Baseline spleen tissue blood flow was significantly decreased by captopril infusion in these lambs (Fig. 3B). Induction of hypoxemia by administration of low oxygen inhaled gas mixture during continuous captopril infusion was associated with significantly increased arterial blood flow to tissues of heart and adrenal (Fig. 3A) and decreased arterial flow to spleen tissue (Fig. 3B). Arterial blood flow to tissues of skeletal muscle (Fig. 3A), liver, ileum, and jejunum (Fig. 3B) were not significantly changed under these conditions. Organ tissue arterial blood flows during recovery were not significantly different from values during inhibitor infusion and normoxemia. Control lambs (Figs. $4 \mathrm{~A}$ and $4 \mathrm{~B}$ ) responded to hypoxemia in a similar manner as captopril-treated lambs, except that the change in tissue blood flow in response to hypoxemia for spleen $[\Delta$ spleen $-1.90 \pm 1.30$ versus $-0.90 \pm 0.60 \mathrm{ml} /(\mathrm{min} \cdot \mathrm{g})]$, jejunum $[\Delta$ jejunum $-1.60 \pm 1.30$ versus $0.60 \pm 2.00 \mathrm{ml} /(\mathrm{min} \cdot \mathrm{g})]$ and ileum $[\Delta$ ileum $-0.32 \pm 0.29$ versus $0.03 \pm 0.40 \mathrm{ml} /(\mathrm{min} \cdot \mathrm{g})]$ were significantly different $(P<0.05)$ in control versus captopriltreated lambs. The \% change in blood flow to spleen tissue with hypoxemia, however, was not significantly different in control versus captopril-treated lambs $(60 \pm 32$ versus $66 \pm 30 \%, P>0.5)$.

\section{DISCUSSION}

ACE inhibitor administration in situations in which the RAA system is known to be activated, such as sodium depleted states and renovascular hypertension, is associated with decreased arterial pressure (11). Newborns have increased activity of the RAA system $(12,15,18-20,24-26,30)$ and the current study demonstrated a significant decline in arterial pressure in response to ACE inhibitor in maturing lambs. ACE inhibitor may produce decreased arterial pressure by inhibiting AII formation and thus withdrawing the vasoconstrictive effects of AII. But the mechanism of the decline in arterial pressure in response to $\mathrm{ACE}$ inhibitor in immature lambs of the current study is not known. Studies in adult animals suggest that AII is involved in the maintenance of arterial pressure during sodium depletion through involvement in homeostatic baroreceptor reflex activity as well as direct vasoconstrictor action (7). The present study demonstrated a decline in arterial pressure in response to ACE inhibitor in immature lambs, which was not accompanied by an increase in 


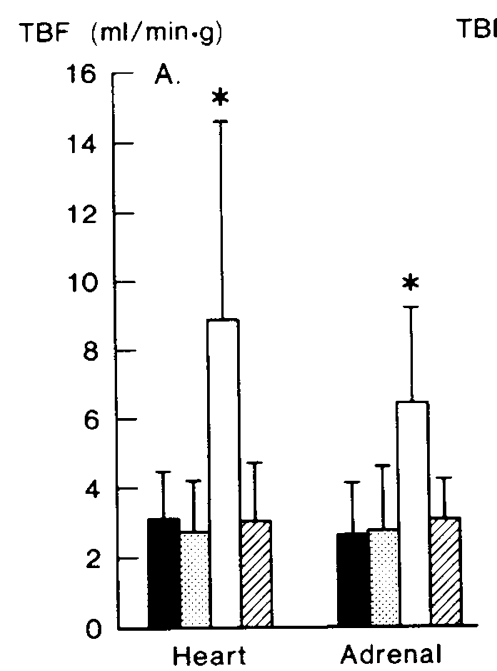

TBF $(\mathrm{ml} / \mathrm{min} \cdot \mathrm{g})$

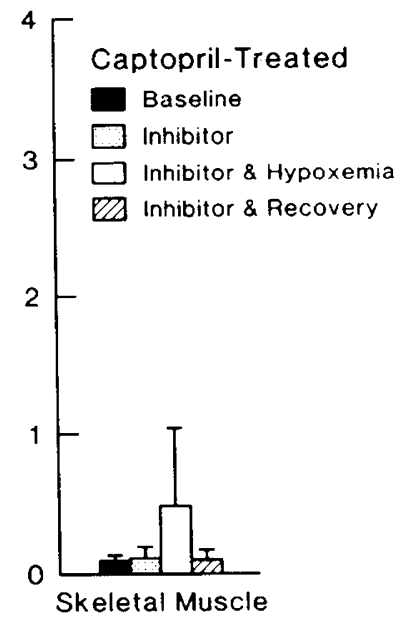

TBF

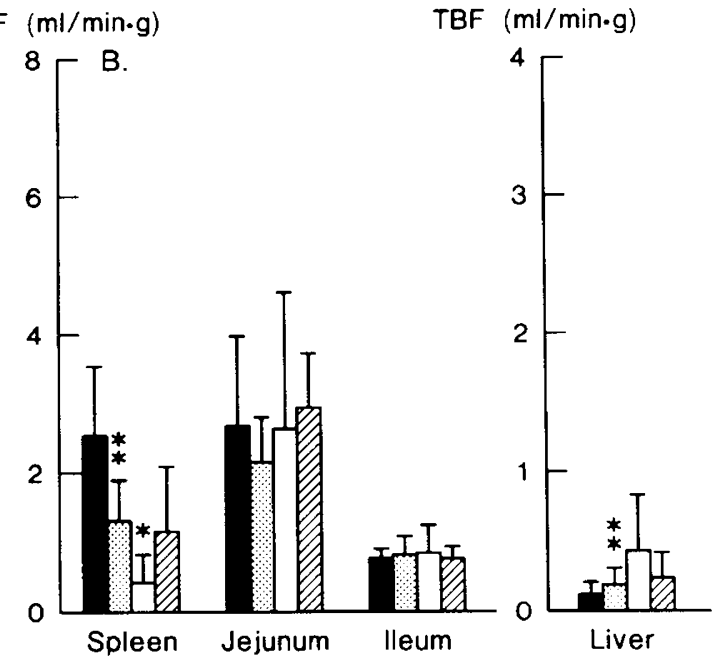

Fig. 3. (A and $B$ ) Organ tissue arterial blood flow (TBF) values under conditions of baseline, inhibition of converting enzyme (Inhibitor), inhibition of converting enzyme plus hypoxemia (Inhibitor \& Hypoxemia), and inhibition of converting enzyme plus recovery (Inhibitor \& Recovery) in captopril-treated lambs. Values are mean \pm S.D., $n=13 .{ }^{*}$ Value is significantly different from Inhibitor period, $P<0.05 .{ }^{* *}$ Value is significantly different from baseline, $P<0.05$.

heart rate. These data suggest that the ACE inhibitor may have reset baroreceptor reflex activity in a similar fashion as that seen in adult dogs (7), but this mechanism was not specifically investigated. HR increased in an appropriate fashion in response to hypoxemia during ACE inhibition in the current study, demonstrating that the heart rate responses were still sensitive to such stimulation.

In contrast, $\mathrm{ACE}$ inhibitor appears not to influence baseline organ tissue blood flow in immature lambs, except to increase arterial flow to liver tissue and decrease arterial flow to spleen tissue. The explanation for a selective effect of ACE inhibition on liver and spleen blood flow is not evident. The dual blood supply to liver tissue may be important in this selective response.

Hypoxemia is a common complication in the perinatal period. Hypoxemia in fetal $(5,17)$ and newborn $(2,3)$ experimental animals is associated with alterations of organ tissue arterial blood flow. Previous work from our laboratory in chronically-catheterized lambs of similar postnatal age as those in the present study demonstrated that hypoxemia induced significant declines in spleen, kidney, ileum, and jejunum tissue blood flow with significant increases in blood flow to heart and adrenal tissues (31). These responses are similar to those seen in adults (8). Redistri- bution of blood flow appears to be accomplished by a local effect of hypoxia to dilate coronary vessels, and by the chemoreceptor reflex, which maintains arterial pressure, produces vasoconstriction in skeletal muscle and splanchnic vascular beds, and produces dilatation in coronary vessels (8). However, increased activity of the RAA system, as suggested by increased plasma renin activity, Aldo concentration $(22,30)$, plasma renin concentration (2), renin secretion rate $(14,32)$, and serum and lung ACE activity (14), has been suggested as a possible mediator of vascular responses to hypoxemia. Furthermore, the role of ACE activity and AII in the chemoreceptor reflex is unknown. The results of the current study suggest that inhibition of ACE activity with captopril alters the hypoxemia-induced redistribution of arterial blood flow by maintaining intestinal perfusion during hypoxemia. This effect may be of clinical importance in that intestinal ischemia has been suggested as an etiology for necrotizing enterocolitis in asphyxiated newborns (2).

The mechanism of this ACE inhibitor-induced alteration of hypoxemia response is unknown. The selectivity of the effect for intestinal vascular beds suggests that an overall resetting of the chemoreceptor reflex has not occurred. Rather, AII may be a predominant vasoconstricting influence on intestinal vascular beds during hypoxemia. Because $\mathrm{ACE}$ is also involved in bradykinin catabolism, kinins may play a role in the $\mathrm{ACE}$ inhibitor-induced
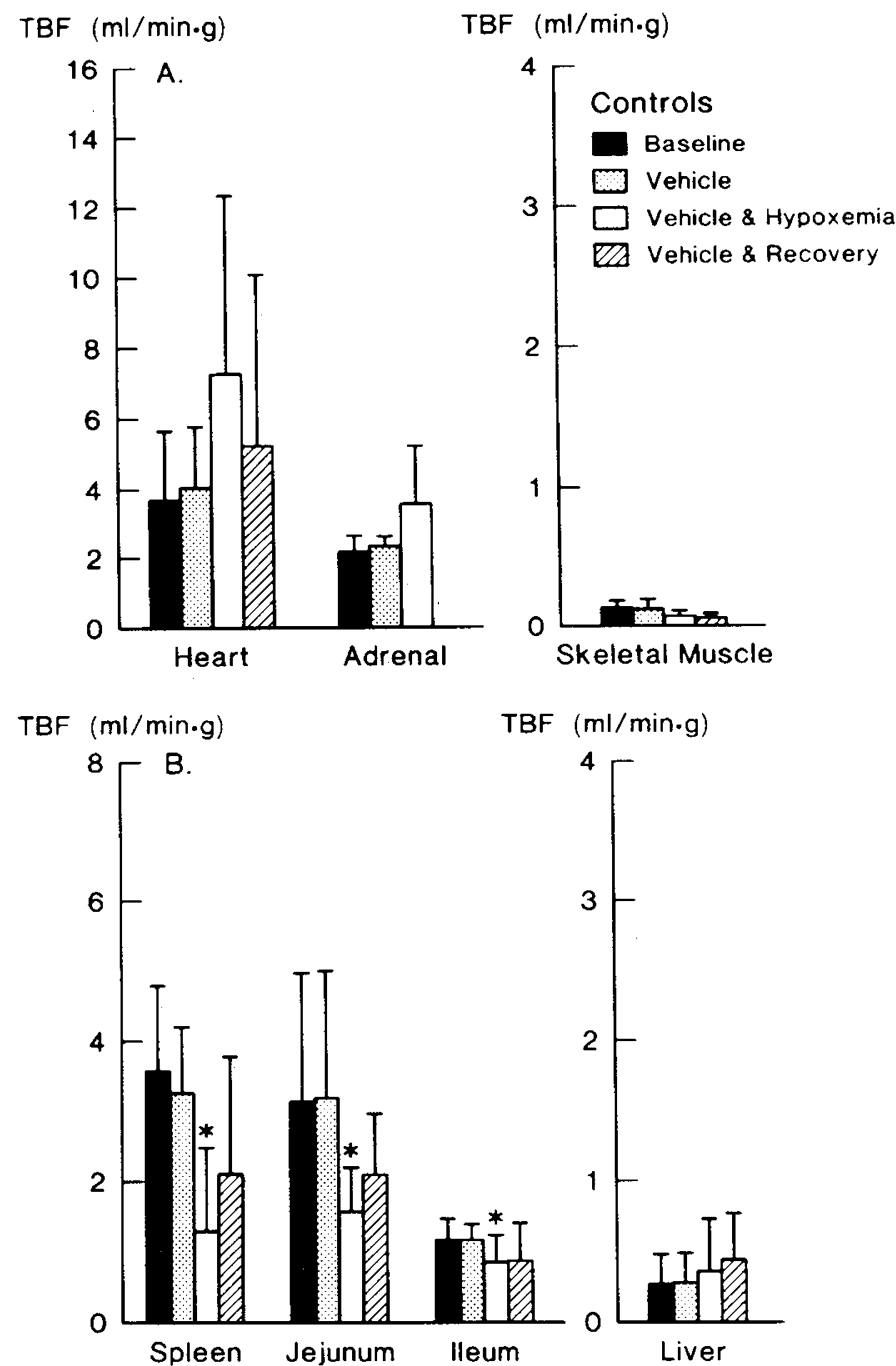

Fig. 4. (A and B) Organ tissue arterial blood flow (TBF) values under conditions of baseline, vehicle infusion (Vehicle), vehicle infusion plus hypoxemia (Vehicle \& Hypoxemia), and vehicle infusion plus recovery (Vehicle \& Recovery) in control lambs. Values are mean \pm S.D., $n=8$. ${ }^{*}$ Value is significantly different from vehicle period, $P<0.05$. 
effects, but were not specifically examined in the current study. Also, AII interacts with adrenergic (33) and vasopressin $(16,24)$ responses. But responses of circulating levels of epinephrine, norepinephrine, and vasopressin to hypoxemia appear not to be influenced by converting enzyme inhibition with captopril (Weismann, unpublished observations).

In summary, angiotensin converting enzyme inhibition with captopril in chronically-catheterized lambs was associated with (1) reduction of baseline arterial pressure; (2) no change in baseline organ tissue arterial blood flows, except for an increase in arterial flow to liver tissue and a decrease in blood flow to spleen tissue; and (3) alteration of hypoxemia-induced organ tissue blood flow redistribution to preserve intestinal tissue perfusion.

\section{REFERENCES AND NOTES}

1. Alward, C. T., Hook, J. B., Helmrath, T. A., and Bailie, M. D.: Effects of asphyxia on renal function in the newborn piglet. Pediatr. Res., 12: 225 (1978).

2. Alward, C. T., Hook, J. B., Helmrath, T. A., Mattson, J. C., and Bailie, M. D.: Effects of asphyxia on cardiac output and organ blood flow in the newborn piglet. Pediatr. Res., 12: 824 (1978).

3. Boda, D., Bélay, M., Eck, E., and Csernay, L.: Blood distribution of the organs examined by ${ }^{86} \mathrm{Rb}$ uptake under intrauterine conditions, in the newborn, in normal and hypoxic rabbits. Biol. Neonate, 18: 71 (1971).

4. Cain, M. D., Coghlan, J. P., and Catt, K. J.: Measurement of angiotensin-II in blood by radioimmunoassay. Clin. Chem. Acta, 39: 21 (1972).

5. Cohn, H. E., Sacks, E. J., Heymann, M. A., and Rudolph, A. M.: Cardiovascular responses to hypoxemia and acidemia in fetal lambs. Amer. J. Obs. Gynecol., I20: 817 (1974).

6. Dillon, M. J. and Ryness, J. M.: Plasma renin activity and aldosterone concentration in children. Br. Med. J., 4: 316 (1975).

7. Hatton, R., Clough, D., Faulkner, K., and Conway, J.: Angiotensin-converting enzyme inhibitor resets baroreceptor reflexes in conscious dogs. Hypertension, 3: 676 (1981).

8. Heistad, D. D. and Abboud, F. M.: Circulatory adjustments to hypoxia. Circulation, 61: 463 (1980).

9. Heymann, M. A., Payne, B. D., Hoffman, J. I. E., and Rudolph, A. M.: Blood flow measurements with radionuclide-labeled particles. Cardiovasc. Dis., 20: 55 (1977)

10. Hiner, L. B., Gruskin, A. B., Baluarte, H. J., and Cote, M. L.: Plasma renin activity in normal children. J. Pediatr., 89: 258 (1976).

11. Hollenberg, N. K.: Pharmacologic interruption of the renin-angiotensin system. Ann. Rev. Pharmacol. Toxicol., 19: 559 (1979).

12. Kotchen, T. A., Strickland, A. L., Rice, T. W., and Walters, D. R.: A study of the renin-angiotensin system in newborn infants. J. Pediatr., 80: 938 (1972).

13. Makowski, E. L., Meschia, G., Droegemuller, W., and Battaglia, F. C.: Measurement of umbilical arterial blood flow to the sheep placenta and fetus in utero. Circ. Res., 23: 626 (1968).

14. Mattioli, L., Zakheim, R. M., Mullis, K., and Malteni, A.: Angiotensin-I-convetting enzyme in idiopathic respiratory distress syndrome of the newborn infant and in experimental aveolar hypoxia in mice. J. Pediatr., 87: 97 (1975).

15. Mott, J. C.: The place of the renin-angiotensin system before and after birth. Br.
Med. Bull., $31: 44$ (1975).

16. Mouw, D.. Bonjour. J. P., Malvin, R. L., and Vander, A. J.: Central action of angiotensin in stimulating ADH release. Am. J. Physiol., 220: 239 (1971).

17. Peeters, L. L. H., and Sheldon, R. E., Jones, M. D. Jr., Makowski, E. L., and Meschia, G.: Blood flow to fetal organs as function of arterial oxygen content. Amer. J. Obs. Gynecol., 135: 627 (1979).

18. Pipkin, F. B., Kirkpatrick, S. M. L., Lumbers, E. R., and Mott, J. C.: Renin and angiotensin-like levels in foetal, newborn and adult sheep. J. Physiol., 24I: 575 (1974).

19. Pohlova, I. and Jelinek, J.: Components of the renin-angiotensin system in the rat during development. Pflügers Arch., 351: 259 (1974).

20. Richer, C., Hornych, H., Amiel-Tison, C., Relier, J-P., and Giudicelli, J-F. Plasma renin activity and its postnatal development in preterm infants. Biol. Neonate, 31: 301 (1977).

21. Robillard, J. E., Ramberg, E., Sessions, C., Consamus, B., VanOrden, D., Weismann, D., and Smith, F. G., Jr.: Role of aldosterone on renal sodium and potassium excretion during fetal life and newborn period. Dev. Pharmacol. Ther., 1: 201 (1980).

22. Robillard, J. E., Weitzman, R. E., Burmeister, L., and Smith, F. G. Jr.: Developmental aspects of the renal response to hypoxemia in the lamb fetus. Circ. Res., 48: 128 (1981).

23. Sassard, J., Sann, L., Vincent, M., Francois, R., and Cier, J. F.: Plasma renin activity in normal subjects from infancy to puberty. J. Clin. Endocrinol. Metab., 40: 524 (1975).

24. Siegel, S. R. and Fisher, D. A.: Ontogeny of the renin-angiotensin-aldosterone system in the fetal and newborn lamb. Pediatr. Res., 14: 99 (1980).

25. Solomon, S., Iaina, A., Eliahou, H., and Serban, I.: Postnatal changes in plasma and renal renin of the rat. Biol. Neonate, 32: 237 (1977).

26. Spitzer, A.: Renal physiology and functional development. In: C. M. Edelmann Jr., Ed.: Pediatric Kidney Disease, Volume I, p. 55 (Little, Brown and Company, Boston, MA, 1978).

27. Stalker, H. P., Holland, N. H., Kotchen, J. M., and Kotchen, T. A.: Plasma renin activity in healthy children. J. Pediatr., 89: 256 (1976).

28. Steel, R. G. D. and Torrie, J. H.: Principles and Procedures of Statistics, p. 183 (McGraw-Hill Book Company, Inc., New York, NY, 1960).

29. VanAcker, K. J., Scharpe, S. L., Deprettere, A. J. R., and Neels, H. M.: Reninangiotensin-aldosterone system in the healthy infant and child. Kidney Int., 16: $196(1979)$

30. Weismann, D. N. and Clarke, W. R.: Postnatal age-related responses to hypoxemia in lambs. Circ. Res., 49: 1332 (1981).

31. Weismann, D. N. and Herrig, J.: Effect of hypoxemia on tissue oxygen delivery in lambs. Pediatr. Res., 15: 474 (1981)

32. Weismann, D. N. and Williamson, H. E.: Hypoxemia increases renin secretion rate in anesthetized newborn lambs. Life Sci., 18: 1887 (1981).

33. Zimmerman, B. G.: Adrenergic facilitation by angiotensin: does it serve a physiologic function? Clin. Sci., 60: 343 (1981).

34. This work was partially supported by USPHS Grants HD-11466 (J.E.R.) and HL-14388 (J.E.R.), and grant No. 81-G-42 from the Iowa Affiliate of the American Heart Association (D.N.W.). Dr. Weismann is the recipient of Clinical Investigator Award AM-00656. Dr. Robillard is the recipient of Research Career Development Award HD-00254

35. Requests for reprints should be addressed to: Dr. Douglas N. Weismann, Department of Pediatrics. University Hospital, Iowa City, IA 52242.

36. Received for publication March 4, 1982.

37. Accepted for publication August 5, 1982. 